\title{
高効率に関わる心と理論の隙間
}

\section{Theoretical and Spiritual Void Concerned with High Efficiency}

\author{
正 山田 豊久（公益社団法人 日本技術士会中部本部 ET の会）
}

Toyohisa YAMADA

Society of ET, C/O The Institution of Professional Engineers , Japan, 5-4-14 Meieki, Nakamuraku, Nagoya 450-0002, Japan

Key Words: High Efficiency, Theoretical Efficiency, Perpetual Motion Machine

\section{1. 諸元}

もし，画期的な効率の発電装置の開発に投資しないかと言 われたら，にわかには応じないことが常識的な姿勢である. しかし, 東日本大震災のもたらしたエネルギクライシスによ り，これまでのエネルギに対する信頼関係が崩壊すると，よ り安心な，永続するエネルギへの期待が高まると，すべてが 麻痺し, 高効率ということばが, 机上の空論のように現れる. ここでは，熱エネルギ利用に関する特許の事例を通して，人 間の欲望と自然法則の限界について考えたい.

\section{2. 永久機関に潜む心理上のトリック}

永久機関に関する特許の出願は絶えることがない。いかな る特許も自由に出願できるが，特許と技術とは別物である.

図 1 は, 2013 年に公開された永久機関の特許の一つである. 錘が上に来れば錘が収納されて容積が小さくなり，錘が下に なると錘が出て容積が大きくなる浮子がベル卜上に連なっ て配置され，この錘の出入りによる容積差で, 浮力の差がべ ルトを永久に回し続けるというものである.

定性的に考えると成立しそうであるが，錘が下になって浮 子から出る条件(1)式と浮子が浮き上がる条件(2)式を両立さ せると, (3)式の通り, 上面より負圧で吸い上げる結果になる.

$\mathrm{P}_{\mathrm{H}} \mathrm{S}<\mathrm{Wg}$

$\mathrm{Wg}<\rho g \mathrm{SL}=\left(\mathrm{P}_{\mathrm{H}}-\mathrm{P}_{\mathrm{L}}\right) \mathrm{S}$

$\mathrm{P}_{\mathrm{H}} \mathrm{S}<\left(\mathrm{P}_{\mathrm{H}}-\mathrm{P}_{\mathrm{L}}\right) \mathrm{S} \Rightarrow 0<-\mathrm{P}_{\mathrm{L}}$

これは，通常の設計の場合，検討不十分となる失態だが， 大きな期待で泠静さを失うと, 定性的な検討段階で見落とす 事になる. すなわち, 過度な期待は不都合な事実を封印する.

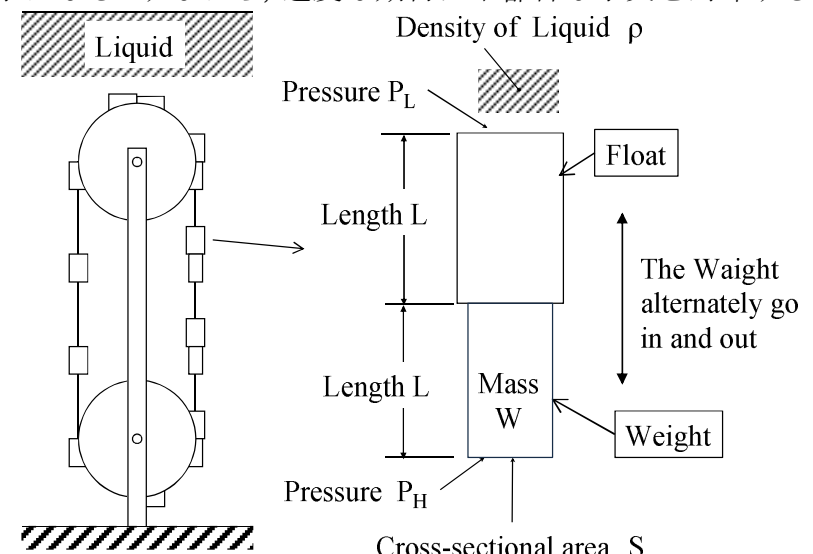

Fig.1 Power generator using buoyancy energy

\section{3. 効率の一人歩き}

\section{1 効率に対する思い込み}

流体を攪拌して発生する熱を測定する実験からは, 熱とは 運動エネルギが形を変えたものであることが示される。ここ では，仕事が熱に変化するならば，熱が仕事にならないかと いう疑問がよぎる。これが形を変えると，熱効率 100\%の熱 機関ができないかという期待に変わる.
しかし，現代の熱機関に関する一般的な知識からは，100\% の熱効率の熱機関が不可能であることが周知されているの で，あくまで高効率の熱機関の実現に対して努力が成される. このこと自体は非常に重要なことであるが, ここで生じ得る 間違いは, 効率が一人歩きして, 思い込みで技術的な判断が なされることである.

たとえば，夏場のエアコンの排気が暑苦しいので，その熱 を汲上げて発電できないかと考えることがある。この様な必 要性に対して, ヒートポンプと熱機関を組合せた特許がある. ここでの考え方の骨子は, ランキンサイクルによるヒートポ ンプの COP (成績係数) が $100 \%$ を超えていることが一般的 なため, 熱機関の効率 $\eta$ が COP との積により倍増できない かということである.

図 2 は, エアコン等のヒートポンプで汲上げた熱で, 直接, 熱機関を駆動することが可能な系の基本的な回路図である. この系全体での熱効率 $\eta_{0}$ は次のようになる.

$\eta_{0}=\left(\mathrm{W}_{\mathrm{G}}-\mathrm{W}_{\mathrm{P}}-\mathrm{W}_{\mathrm{C}}\right) / \mathrm{Q}_{1}$

ここで注目すべきことは COP の定義である。COP とは、 図2での熱交換器での交換熱量と圧縮機の駆動電力との比で、 (5)式の形となり，供給熱量との比ではない.

$$
\mathrm{COP}=\mathrm{Q}_{\mathrm{EX}} / \mathrm{W}_{\mathrm{C}}
$$$$
\eta=\left(\mathrm{W}_{\mathrm{G}}-\mathrm{W}_{\mathrm{P}}-\mathrm{W}_{\mathrm{C}}\right) / \mathrm{Q}_{\mathrm{EX}}
$$

これらから, COP と $\eta$ との積を見ると(7)式のようになる ので, 系全体の熱効率とは全くの別物であることが分かる.

$$
\mathrm{COP} \times \eta=\left(\mathrm{W}_{\mathrm{G}}-\mathrm{W}_{\mathrm{P}}-\mathrm{W}_{\mathrm{C}}\right) / \mathrm{W}_{\mathrm{C}}
$$

このことは, 効率が無次元の比率であるため, 本来の意味 がすり替えられ, 効率ということばに対する勝手な思い込み が生じるということである.

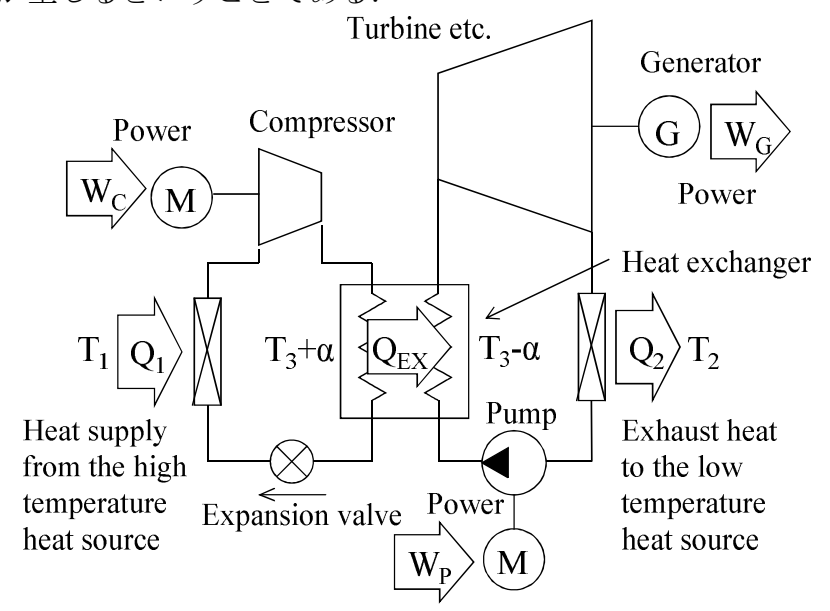

Fig. 2 Heat engine to be driven by the heat pump

\section{2 心の隙を埋める特許の権威}

特許法では, 新規性のあるのうち高度のもので産業上利用 することができれば，特許を受けることが出来る。この特許 要件は非常に広義なもので, 明細書で発明の構成とその作用 効果を説明することで, 特許の請求範囲を限定できる. 
このため, 図 2 の系については動力増幅装置に関する発明 として限定し, (7)式のヒートポンプの動力に対する発電機の 出力に関する効率を上げることを目的とすることで, 特許上 の権利を主張することが可能である. (4)式による系全体での 熱効率 $\eta_{0}$ はカルノ効率の制約を受けるが，熱源の温度差を 相応に取ることにより, (7)式による動力増幅装置としての効 率が 100\%を超えるという主張も可能になる.

このことは, 審査請求の後に登録査定を受けることができ れば, 特許公報上, 寸なわち公文書上での独自の基準を設け ることが可能で, 独自の基準を世間に公表して主張すること も，当然の権利として可能になることを意味している。これ は、発明そのものが自然法則を利用した技術的思想の創作で あることによる。

\section{4. 永久機関が付け入る理論の隙 \\ 4.1 熱効率 100\%の条件}

自然法則として動力としての熱効率に限界があるが，す心゙ ての人の理解を得るには，ほど遠い道のりが存在する. 高効 率の限界を示すのが，(8)式のカルノ効率である. 低温熱源温 度 $\mathrm{T}_{2}$ が 0 , すなわち, 絶対零度であれば， $\eta$ が $100 \%$ となっ て，第 2 種永久機関が成立する.

$$
\eta=1-\mathrm{T}_{2} / \mathrm{T}_{1}
$$

$\mathrm{T}_{1}$ : 高温熱源温度 $[\mathrm{K}]$

$\mathrm{T}_{2}$ : 低温熱源温度 $[\mathrm{K}]$

機械工学では, 理祖気体による定義でカルノサイクルを教 えられるが，ここでは，可逆サイクルをカルノサイクルとし て定義する.これは，高温熱源と低温熱源の温度が同一なら ば相異なる可逆サイクルが存在しないことによる。この性質 を用いたのが熱力学温度の定義である.

図 3 は熱力学温度を定義するサイクルの関係を示す. 図中 のサイクルはすべてカルノサイクルである.これらのサイク ルにより低温熱源 $\left(\theta_{3}\right)$ の温度 $\mathrm{T}_{3}$ を基準とした低温熱源 $\left(\theta_{2}\right)$ の温度 $\mathrm{T}_{2}$ は移動する熱量の関数により次のように表される.

$$
\begin{aligned}
& \frac{\mathrm{T}_{3}}{\mathrm{~T}_{2}}=\frac{\mathrm{f}\left(\theta_{1}, \theta_{3}\right)}{\mathrm{f}\left(\theta_{1}, \theta_{2}\right)}=\frac{\mathrm{Q}_{3}}{\mathrm{Q}_{2}} \\
& \mathrm{f}\left(\theta_{1}, \theta_{3}\right)=\mathrm{Q}_{3} / \mathrm{Q}_{1} \\
& \mathrm{f}\left(\theta_{1}, \theta_{2}\right)=\mathrm{Q}_{2} / \mathrm{Q}_{1} \\
& \text { ここでは, } \mathrm{Q}_{1}>0 、 \mathrm{Q}_{2}>0 、 \mathrm{Q}_{3}>0 \text { である. }
\end{aligned}
$$

この定義からは，カルノサイクルを崩壊さない前提では, 任意の高温熱源 $\left(\theta_{1}\right)$ の温度 $\mathrm{T}_{1}$ に対しても $\mathrm{T}_{1}>\mathrm{T}_{2}>\mathrm{T}_{3}>0$ の状態 であって, 絶対零度は極限として存在するものになる.

\section{2 条件の限定による理論の切り崩し}

熱力学温度は, 万人が理解できているとは言いがたく, 絶 対零度が未発見であるとの主張を遮ることも難しい. たとえ ば、通常考えるとおり, 熱源間の温度が同一の条件ではカル ノサイクルの仕事 $\mathrm{W}_{13}$ が 0 であると解勫した場合, 図 3 の熱 力学温度の極限の限界を切り崩すことになる。

この場合は, 特異点としての絶対零度の存在を認めるとい う主張になる. すなわち, $\mathrm{W}_{13}=0$ ならば, $\mathrm{W}_{12}=-\mathrm{W}_{23}$ となり, 可逆サイクルとして成立するので, 低温熱源 $\left(\theta_{2}\right)$ と低温熱源 $\left(\theta_{3}\right)$ 間についての熱の移動量を $\mathrm{Q}_{2}{ }_{2}, \mathrm{Q}_{3}{ }_{3}$, 仕事を $\mathrm{W}_{23}{ }_{23}$ とし て区別すると，次の関係が保存される.

$$
\mathrm{Q}_{2}{ }_{2}-\mathrm{Q}_{3}{ }_{3}=\mathrm{W}^{\prime}{ }_{23}
$$

$$
\text { ここでは, } \mathrm{Q}_{1}-\mathrm{Q}_{3}=0, \mathrm{Q}_{1}>0, \mathrm{Q}_{2}>0, \mathrm{Q}_{3}>0, \mathrm{Q}_{2}=-\mathrm{Q}_{2}, \mathrm{Q}_{3}=-\mathrm{Q}_{3} \text {, }
$$

$\mathrm{W}_{23}{ }_{23}=-\mathrm{W}_{23}$ である.

これは，互いに可逆なサイクルを設定することにほかなら ず, 任意の高温熱源 $\left(\theta_{1}\right)$ に対応する低温熱源 $\left(\theta_{3}\right)$ が同一の温 度であるならば, 低温熱源 $\left(\theta_{2}\right)$ が特定の温度で存在し得るこ とを示す。その結果，絶対零度が未発見なのではないかとい
う仮説が生じ，第 2 種永久機関の存在，さらには, 統計力学 上の負の絶対温度が存在から，熱効率が $100 \%$ を超える第 1 種永久熱機関の可能性にまで言及できる口実を与える。これ が永久機関の付け入る隙と考えられる.

しかし，任意の高温熱源 $\left(\theta_{1}\right)$ に対応する低温熱源 $\left(\theta_{3}\right)$ が同 一の温度であることは, 熱力学温度を定義する系に熱の出入 がなく, 温度を定義することのできる熱の流れが存在してい ないことになる。このことは, 熱の出入りのない系での熱機 関は永久機関にほかならず, 永久機関では温度が定義できな いことも意味している.

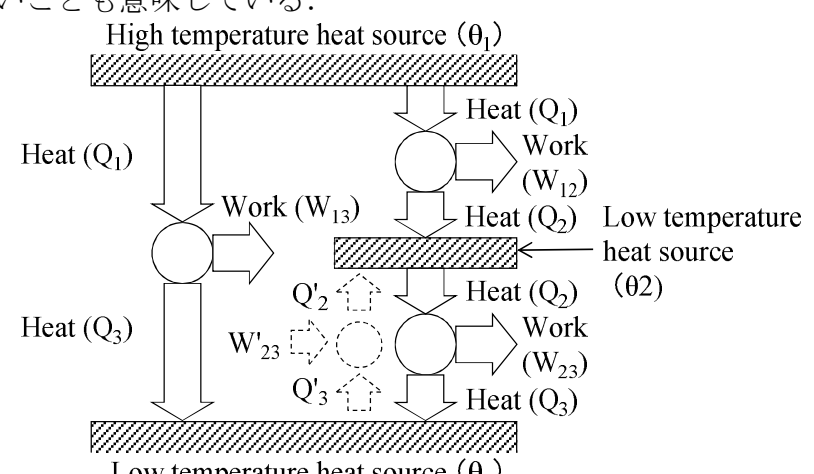

Low temperature heat source $\left(\theta_{3}\right)$

Fig.3 Heat cycles that define the thermodynamic temperature

\section{5. 結言}

自らが正しいと信じ込ませるのに便利な道具が，皮肉にも， 科学技術に関する高等な専門的応用能力である. 万人に通用 することが普遍性の根本条件であり，偽物についてはこの条 件により除外される。しかし，一部の人の信頼を得る事がで きれば十分となると話は早い。信じる人を限定すれば良い.

特許についても同じである．権利化に対しては，担当の審 查官の拒絶査定を覆すだけの主張をすれば十分で, 裁判にで もならなければ学術的な科学的根拠による証明など何ら必 要ない，さらには，資金を引き出す等の目的で，信頼を得る 標的を別に取り, 権威付けを目的とした特許出願のみを行っ て審査請求しない悪意の選択もある.

しかし，最も恐れなければならないのが，自分が自分自身 にごまかされてしまう場合である。いざ実証という段階で, 計測值が間違いを指摘しているにもかかわらず，実験機が見 かけ上動いてしまい, 計測誤差として測定值に補正が必要と 判断したら, 最後まで間違いに気がつかないであろう。この 場合は，実際に失敗して，間違いに気がつく方が良い.

困難な状況下での開発継続には，モチベーション維持のた めの自画自賛も，信念も必要である. しかし，技術に対する 期待は，第三者よりも技術開発の当事者の方が大きい。この ため，事故の回避が開発目的ならば，過度な期待が不都合な 事実を封印して悲惨な結果を招くことにもなりかねない. 過 度な期待は，物事をねじ曲げ，すり替えるよう自らを仕向け ることを忘れてはならない。

\section{参考文献}

1）公開特許公報, 浮力エネルギーを利用した発電装置, 特開 2013-113293

2) 公開特許公報，発電システム，特開 2013-15083

3）特許公報, 高効率駆動装置, 第 2727071 号

4) 原島鮮, 熱力学・統計力学, 倍風館、(1978)

5) 斉藤孟 小泉睦男, 工業熱力学, 共立出版, (1973)

6) 山田豊一, 工業熱力学大要, 理工図書, (1963) 